\title{
Beyond the Colonial/Orientalist Encounter: "European" Cultural Contributions to Arab Modernity
}

\author{
Alaaeldin Mahmoud
}

\begin{abstract}
Albeit what can be described as the "European" contributions to world modernities (with Arab modernity included) are often perceived as a self-evident fact, a scrutinizing look is useful in shedding more light on the mostly ignored European cultural contributions to the Arab Nahdah (Arab Renaissance) and modernity that were neither colonial nor orientalist, especially during the last quarter of the nineteenth century and the first half of the twentieth century, with particular focus on Egypt and the Levant. This study examines the contributions of Europeans who settled in Egypt and the Levant, such as the Hungarian photographers Otto Schoefft (1833-1890s) and Zoltan Kluger (18951977), Hungarian illustrator and painter Éric de Nemès (1910-??), the Spanish cartoonist Juan Santez and the Armenian cartoonist Alexander Saroukhan (1898-1977), to name a few. It also challenges the perception that the Europeans who migrated to and settled in the Arab region (especially in the early twentieth century) were living in "cultural ghettos." Instead, the work of the above artists, literati and others shows that the European communities in Egypt and the Levant were cultural agents who contributed to the literary and artistic landscapes in their respective fields of expertise.
\end{abstract}

Keywords: Colonial encounter, Orientalism, the Nahdah, Arab modernity

Biography: Alaaeldin Mahmoud (M.A. and Ph.D., Ain Shams University, Cairo, Egypt) is an Assistant Professor of English who teaches English writing and communication in the Liberal Arts Department at the American University of the Middle East in Kuwait. His current research interests include the Arab Nahdah (Arab Renaissance) and modern Arab literatures as well as travel writing/literature within the broader framework of comparative cultural studies. He has translated books into Arabic in travel literature, fiction and comparative literature, such as Giovanni Belzoni's Narrative of the Operations and Recent Discoveries within the Pyramids, Temples, Tombs, and Excavations in Egypt and Nubia (Egypt, 2005); Other Renaissances: A New Approach to World Literature (Kuwait, 2014), and Louis Couperus's Eline Vere (Egypt, 2015). alaaeldin.mahmoud@aum.edu.kw

Whether a consensus can be reached as to the definition or beginnings of European modernity, there is always a hypothetical agreement that this "European" modernity maintains a colonial and/or orientalist relationship with "world" modernities. There is a need to rethink such a hypothetical agreement, which essentializes Europe's colonialism and/or orientalism as being the two core strategies that Europe can offer to deal with the rest of the world's populations politically, socially, economically and culturally. Given the fact that European modernity is 
Mahmoud, Alaaeldin. "Beyond the Colonial/Orientalist Encounter: "European" Cultural Contributions to Arab Modernity." Hungarian Cultural Studies. e-Journal of the American Hungarian Educators Association, Volume 12 (2019) DOI: 10.5195/ahea.2019.351

closely associated with geographical discoveries that resulted in discovering "The New World," it is equally marked by parallel and/or subsequent "discoveries" of the Old World. Subsequent to colonizing African and Asian lands by the European colonial powers, the "Orient" has had to be "invented." In fact, the Orient, as Edward Said (1994: 1-2), a founding figure in comparative literature and postcolonial studies, has expressed it, "helped to define Europe (or the West) as its contrasting image, idea, personality, experience." What can be understood from Said's words is that the Orient is the exact antithesis of Europe. However, Said also claimed that this Orient is concomitantly "the source of [Europe's] civilizations and languages" (1), which renders it, in Said's own words, "an integral part of European material civilization and culture" (2, emphasis in original). It could be contended that Europe (or interchangeably the "Occident") is likewise "an integral part" of the Orient's material civilization, cultures and languages, especially when it comes to modernity, a period when the European contributions to the Orient appear to be more ubiquitous and far-reaching, as in technology transfer (for example, the introduction of print or railroads). However, Europe is similarly an integral part in the less visible materializations of those contributions, notably in cases that go beyond the colonial/orientalist encounter to those of the European migrants and settlers who, between the early nineteenth century and the first half of the twentieth century, chose to move and settle in Egypt and the Levant for several reasons unrelated to colonialism and/or orientalism.

A growing literature challenges the traditional view of the colonial/Oriental encounter as fixed and essential. In his review of Ellen J. Amster's Medicine and the Saints: Science, Islam, and the Colonial Encounter in Morocco, 1877-1956, Cutler (2014) mentions that "the notion of Western colonial science as a totalizing discourse that created a top-down modernity" (851) has to be challenged. Consequently, this suggestion reiterates that the colonial experience should not essentially produce an either/or relationship of domination and resistance for both the colonizer and the colonized. Rather, any colonial encounter may yield a variety of outcomes or "arts," so to speak, to use Mary Louise Pratt's term in her influential article "Arts of the Contact Zone" (1991). While writing against the backdrop of the Spanish conquest of South America, Pratt defined a contact zone as "social spaces where cultures meet, clash, and grapple with each other" (34); such a definition may well be applicable to any other colonial encounter.

An understanding of the contact zone can be taken a step further so as not to be exclusively limited to the colonial experience. That said, the so-called "arts of the contact zone" are inclusive of any colonial encounter, but should not be limited to it. More specifically, by zooming in on a number of geopolitical spaces such as some urban centers in Egypt and the Levant from the period in question suggests that the waves of European migrations to these countries should not be merely locked into the colonial/colonialized model, given that those migrations happen to come from countries located in the European continent. Such understanding also obscures and oversimplifies the diverse demographic structure of the body of European migrants themselves, in addition to essentializing the complexly multiple roles played by the European migrants and settlers in Egypt and the Levant since the early 1900s, while culminating in the interwar period especially in Egypt, as exclusively military and/or colonial.

Contact zones, namely the major, somehow cosmopolitan urban centers found in the region (such as Alexandria and Cairo in Egypt, Beirut, Damascus, and Aleppo in Syro-Lebanon) were, to varying degrees, "third spaces," to borrow Bhabha's term. As such, these types of places were where the cultures of the European migrants and settlers and that of the local inhabitants of those centers "meet, clash, and grapple with each other." This entails that the colonial and/or 
Mahmoud, Alaaeldin. "Beyond the Colonial/Orientalist Encounter: "European" Cultural Contributions to Arab Modernity." Hungarian Cultural Studies. e-Journal of the American Hungarian Educators Association, Volume 12 (2019) DOI: 10.5195/ahea.2019.351

cross-cultural encounter produced a "hybrid" or a third space "that is neither one nor the other," which is stimulated "because the translation or encounter between different cultural forms occurs in a context where both these spaces are already preoccupied" (Krishna 2009: 95). To illustrate, the co-existence of the European communities and the local inhabitants in the Egyptian, SyroLebanese urban centers helped create those hybrid, third social spaces that cannot be claimed to be either purely European or purely Middle Eastern.

\section{Contesting Modernities in the Contact Zones of the Ottoman Arab vilayets ['Provinces']}

Various cultural aspects of European modernity such as ideas, social and art movements, art forms, pedagogical, financial, administrative and judicial systems, technologies, and even material products were consistently introduced or "exported" to different parts of the world, including the Ottoman Empire and its Arab provinces. European colonialism and/or orientalism were undeniably key factors in the process of such introduction or exportation. Other factors of the transcultural diffusion of European modernity are directly related to the relative ease of and access to travel and movement for Europeans between Europe and the Ottoman Arab lands. Additional "non-colonial" factors in the germination and proliferation of European communities in (former) Ottoman vilayets included the relatively problem-free access to Ottoman territories by European nationals, including labor and economic immigrants. Largely in Egypt and the Arab Mashriq Greek, Armenian, Italian, German, French and British communities worked as a liaison between the European mainland and their respective diasporic countries of residence.

Members of the various European communities who migrated and settled in Egypt and Syro-Lebanon were active agents operative in the center of their corresponding "contact zones." This means that they not only maintained dynamic networking relationships with their respective countries of origin or the European proper, but also (to varying degrees) catered to similar networking connections within their new spaces of residence and settlement. These new European settlers were vacillating between two opposing forces of assimilation and ghettoization. Perceived as catalysts in transferring European cultural modernity to the different parts of the Ottoman Empire, these European immigrants and settlers were not active contributors who were meanwhile living in a vacuum. In fact, they operated within the context of an existent and functional Ottoman "modernity" which was forged through the process of acculturation (Hanioğlu 2012: 50). Additionally, an embryonic Arab modernity was catapulted into being, not only by means of a long, continued European encounter, but also within an overarching Ottoman modernity. In fact, regardless of their diverse languages, religions, or ethnicities, the avant-garde heralds of Arab modernity worked within a space of acculturating or (at times) contesting, co-existing modernities. As was mentioned earlier, Ottoman Turks and/or European or local residents of the Ottoman Arab provinces were usually eager to adopt and "indigenize" the technological/artistic innovations that originated in Europe, such as the press, caricature, theater, photography and even the cinema. Residents of the vibrant Arab urbans centers of the time like Alexandria, Cairo, Beirut, and Aleppo had access to an incredibly broad array of cultural products such as books, magazines, newspapers and other publications printed in a plethora of languages by Greek, Armenian, Turkish and Arabic presses.

Schooling was also another site of contestation between the representatives of Ottoman and western modernities because members of the European communities in Egypt and the Arab Mashriq were keen to establish their own schools in order to "safeguard their identity, language, culture and norms" (Al-Imam 1999: 317). Some immigrants were commissioned to work as 
teachers in the state-owned schools, especially in Muhammad Ali's Egypt, where in his military school students used to be "taught the principles of mathematics, geometry, algebra, drawing and the Italian language; as the majority of the military school instructors were Italian" (Zaydan 2013: 1189). The Italian community members were not only instrumental as teachers, but also proved to be key contributors to the beginnings of theater in the Arab region, particularly in Alexandria, Egypt. Khuri-Makdisi (2010) contends that "[t]he Italian community of Alexandria had historical links to the theater as actors, authors, builders, sponsors and spectators. The first troupes to tour Egypt in the early nineteenth century were Italian" (68). In increasingly cosmopolitan Alexandria, theater, opera and comic shows were solely an Italian business; however, these performative arts were sites of contestation among the "various foreign communities such as the French...Hungarian, Maltese, Greek and Jewish" (Sadgrove 1996: 72), who staged their performances for both their fellow community members and the local audiences. Especially in a once-cosmopolitan Alexandria, theater was a zone for rivalry, not only among the different theatrical troupes representative of their respective European homelands, but also among the nascent "local" theatrical troupes, who either performed translated/adapted plays by "European" theatrical models such as Molière, Jean Racine and William Shakespeare or produced their own "Arabic" plays such as Ya'qūb Șannū', 'Abd Allāh al-Nadīm (1845-1896), and later Aḥmad Shawqī (1868-1932) in Egypt, or Marūn al-Naqqāsh (1817-1855), Khalīl Naṣiff al-Yāzijī (1856-1889) in Lebanon.

The history of early Ottoman/Arab photography clearly presents this medium as a locus of contesting modernities, both global and indigenous. The work of Pascal Sébah (1823-1886), an Ottoman photographer of Syrian-Armenian descent, is exemplary in exhibiting the meaning of the term "indigenous lens" (Ritter and Scheiwiller 2018: 11). Although his work could be labelled as Orientalist, Sébah's photography also brings to light "a vision of the Ottoman Empire different from that of European photographers. In particular, their unique community portraits, which emphasize order and modernity within indigenous historical structures, indicate a perspective that does not fit comfortably into the Orientalist mode" (Woodward 2003: 372).

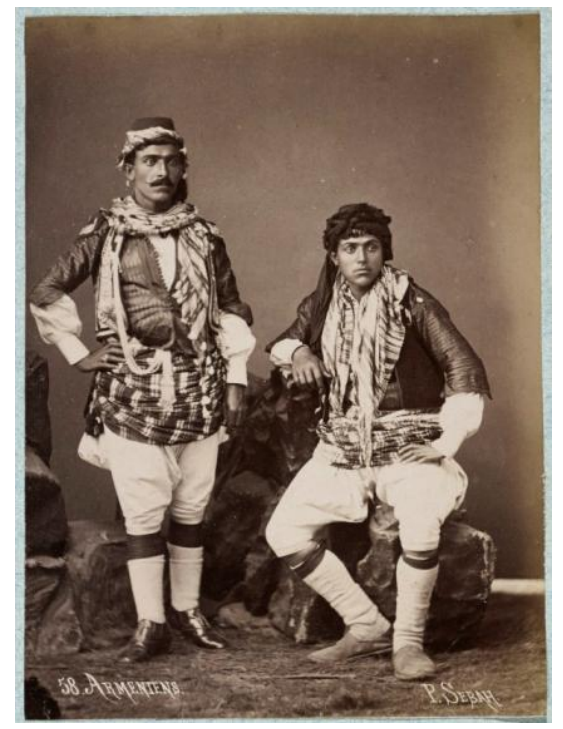

Armenian Men, J. Pascal Sebah, ca. 1875 [Source: Los Angeles, Getty Research Institute (96.R.14, Box 77)] 


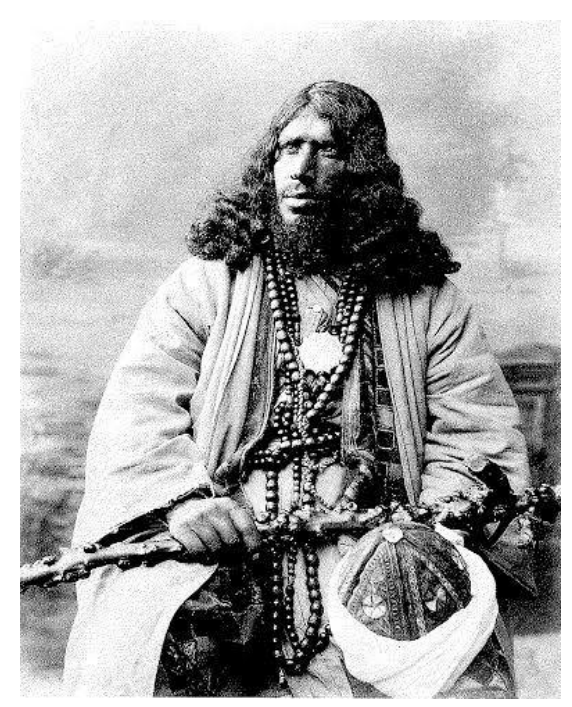

Howling dervish, Pascal Sebah, Egypt, ca. 1875 [Source: Journey through Nostalgia: Pascal Sébah of Istanbul]

The de/Orientalizing nature, so to speak, of early photography in the region is markedly evidenced by the juxtaposing professions of the Jerusalem-born, Christian-Palestinian photographer, Hanna Safieh (1910- 1979), and the Jewish Hungarian photographer, Zoltan Kluger (1895-1977). The very beginnings and subsequent photographic work of both Safieh and Kluger in Palestine/Israel during the 1930s and 1940s are significant in emphasizing the underlying hybrid modernities in the Levant and Egypt, especially during the second half of the nineteenth century until its culmination in the interwar period. Born to a Palestinian Arab family, Hanna Safieh started his photographic profession working at the American Colony photographic department, where he was an apprentice to the Swedish photographer, Eric Matson (1888-1977), with whom he collaborated until the end of Matson's career in Palestine in 1946 (Nassar 2000: 25). Kluger migrated to Germany in the 1920s and worked for the Berliner Illustrierte Zeitung. After meeting Nachman Schifrin, owner of The Press Photo Company in Berlin, both Schifrin and Kluger decided to migrate to Palestine where they founded the Orient Press Photo Company (Sela n.d.). When examining the photographic archive of Kluger and Safieh, we can see that both share an optimistic photographic style that emphasizes a connection to the land and its blessings; such a style was largely reflective of national-consciousness photography on the part of Safieh in antithesis to Kluger's growing commitment to Zionist photography. 

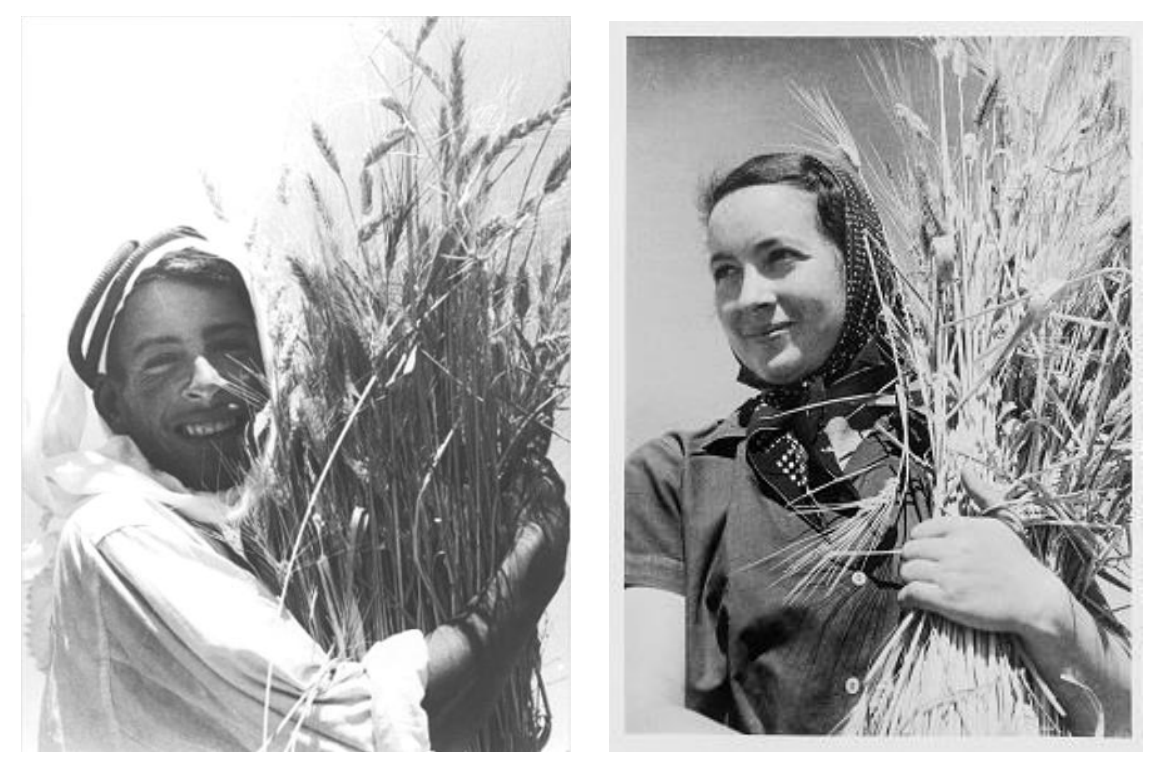

(L) 1. Hanna Safieh, Harvesting of Grain, Late 1930s, Courtesy of Rafi Safieh

(R) 2. Zoltan Kluger, Bnei Brith, One of the Settlers, 1938, Jewish National Fund Photography

Archive, Israel [Source: "In the Eyes of the Beholder - Aspects of Early Palestinian Photography" by Rona Sela]

A hybrid, but rather collaborative sort of modernist photography is evident in the work of another Hungarian photographer, Otto Schoefft (1833-1890s), who was one of the earliest Hungarian/European photographers to live and work in Egypt or the Middle East. In the early 1870s, Schoefft ran a business and studio together with Schier, an Austrian photographer from Vienna. Schoefft and Schier settled in Alexandria and set up their studio which mostly produced carte-de-visite format albumen portraits of Westerners, local residents or visitors, as well as Egyptian "types” (Mészáros 2016: 196).

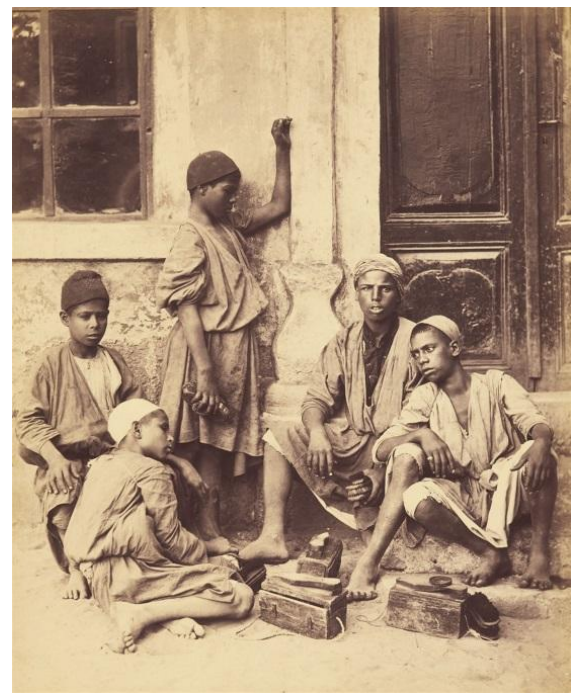

Le Caire pittoresque, Otto Schoefft, Egypt, before 1875

[Source: Lempertz - The international Auction House] 
Mahmoud, Alaaeldin. "Beyond the Colonial/Orientalist Encounter: "European" Cultural Contributions to Arab Modernity." Hungarian Cultural Studies. e-Journal of the American Hungarian Educators Association, Volume 12 (2019) DOI: 10.5195/ahea.2019.351

\section{Collaborative Modernities in Cosmopolitan Arab Urban Centers}

Cosmopolitan Arab urban centers of the Middle East like Alexandria, Cairo, and Beirut, were not only hotbeds of contestation and competition (elements ostensibly associated with a nascent global capitalism), but they were also loci of professional, transcultural collaboration; in short, a sign of ongoing negotiation and hybridity. Since its inception as a European art with the publication of the French Le Caricature and Le Charivari magazines in 1830 and 1832 respectively, together with the British Punch magazine which first appeared in 1841 (Eaman 2009: 103), caricature or cartoon (like theater, cinema or photography) was perceived of as a "Western genre that appeared in the Middle East" (Türköz 2018: 52) with "the first Ottoman caricature appearing in a journal named Istanbul in 1867" (52). With the debut of his Abu Naddara magazine in 1877, Ya'qūb Șannū', an Egyptian-Italian Jew, was a premier harbinger in Egypt in both theater and caricature. Comic magazines or illustrated satirical journalism, however, did not appear in the Levant or Iraq before the second decade of the twentieth century by two forerunners of illustrated journalism who belonged to the native Christian communities in Iraq and Syria respectively.

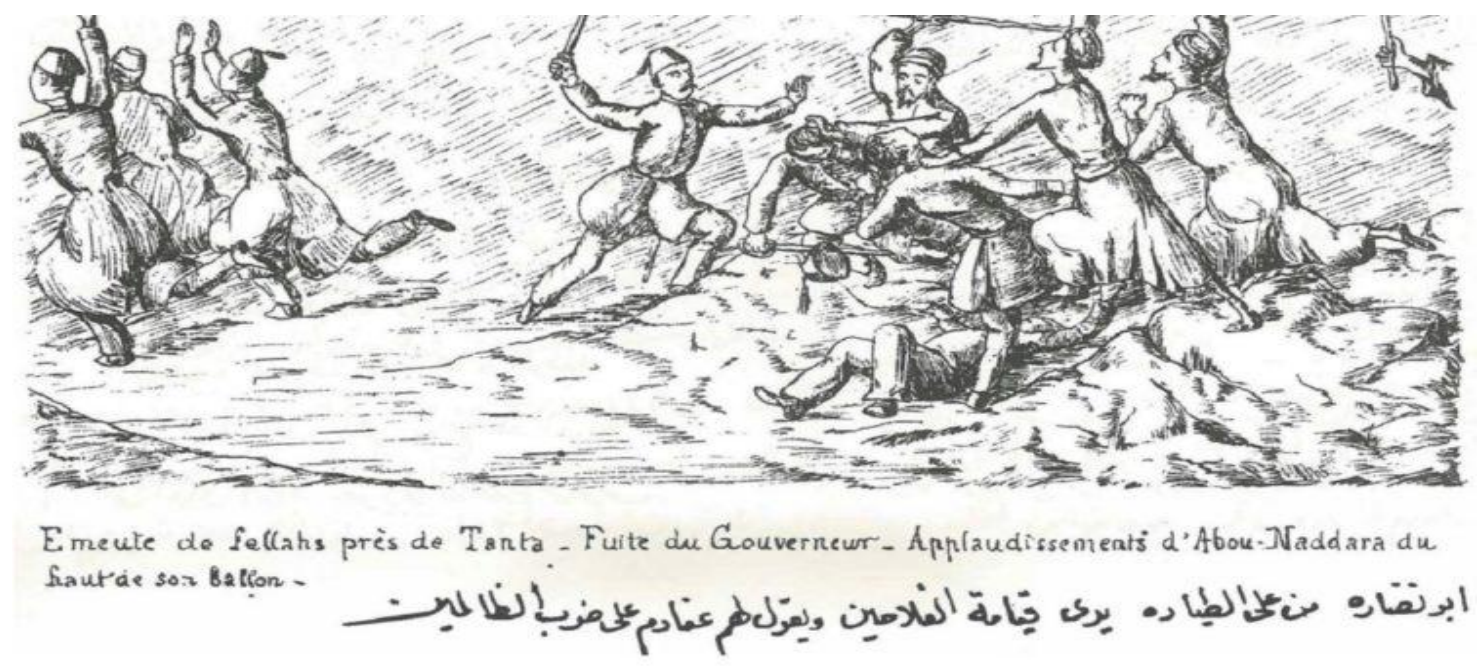

Bilingual (French/Arabic) political cartoon, Abu Naddara, Ya'qūb Șannū‘ (aka James Sanua), [The caption in English translation: 'Abou Naddara from his balloon sees the fellahin riot near Tanta and applauds it due to the Governor's fault']

To meet the fervent demands of a rapidly growing cosmopolitan audience/readership in those cosmopolitan urban centers, collaborative work among journalists, photographers, theater practitioners, book publishers, and filmmakers became the norm rather than the exception. In collaboration with his Lebanese friend Salīm al-Naqqāsh, the Damascus-born Armenian-Syrian Adib Zalmatian, better known by his Arabized name of Adīb Ishāq (1856-1885), authored and translated plays (mostly from French) for the stage in Syria before al-Naqqāsh suggested they move to Alexandria, where "they put on a revised edition of Andromaque, as well as an Arabic version of Charlemagne, and wrote an original play, Coincidences (Ghara'ib al-ittifaq)" (Cole 1999: 141). Later Ishāq turned to journalism; he could arrange a newspaper license and printed 
his first issue of his Misr ("Egypt") in 1877, for which he commissioned Egyptian and nonEgyptian journalists to write like the then novice Egyptian author 'Abd Allāh al-Nadīm.

The modern Arab journalism and art scene, notably in Egypt during the interwar period, were representative in terms of "collaboration" between national (Egyptian) and foreign (varyingly naturalized at times) contributors. One key and active contributor to the modern Egyptian art scene, especially the Egyptian surrealist movement, was the Hungarian artist and illustrator Éric de Némès (1910? - ??). De Némès, who moved to Egypt via Beirut, was one of many expatriate Europeans who contributed to Cairo's artistic buoyance. He was among the artists, writers and activists who belonged to the Egypt-based surrealist collective jama'at alfann wal hurriyyah ['Art et Libertél, 'Art and Liberty Group'] founded in December 1938 to represent "a restless generation of women and men of various social, ethnic and religious backgrounds, Egyptian and non-Egyptian alike, with a heterogeneous platform for cultural and political reform," ("Art et Liberté" 2019). The group included artists like the Egyptians Abdel Hadi El-Gazzar, Kamel El-Telmisany, Georges Henein, and Inji Efflatoun. The Italian Angelo de Riz, who had taken refuge in Egypt from Italian Fascism (Gharieb 1986: 2), the British Robert Medley and Roland Penrose, as well as two female artists, the British-Armenian Ida Kar also numbered among this collective's members. Further artists included the American photographer and photojournalist Lee Miller who, through her connections and her art, did much to strengthen the links between the Egyptian and European Surrealists as well as play a pivotal role along with the other women artists of the movement like as Nimr and Efflatoun to Marie Cavadia-Riaz, a writer and patron whose literary salon was vital to the Cairo avant-garde (Rubinstein 2017: 82). The list cannot be complete without the Cairo-based Armenians, Saroukhan and Van Leo or the Hungarian-Jewish Etienne Sved, who fled Hungary for Cairo during the war (Liverpool 2017). Like his fellow European near contemporaries, de Némès was thoroughly integrated into the modern Egyptian cultural life and scene of his new somehow voluntary "exile," to the extent that led him to rise as a key active contributor therein.

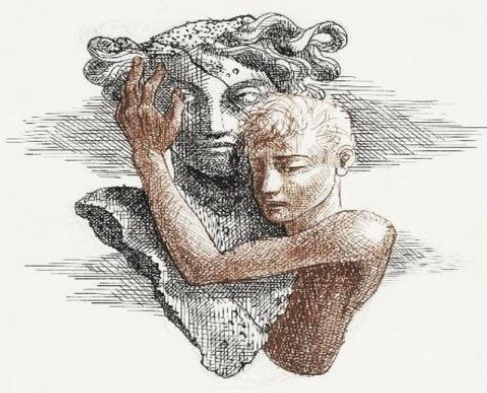

Éric de Némès, Youth, 1945. [Courtesy H.E. Sheikh Hassan M. A. Al Thani Collection] 
Mahmoud, Alaaeldin. "Beyond the Colonial/Orientalist Encounter: "European” Cultural Contributions to Arab Modernity." Hungarian Cultural Studies. e-Journal of the American Hungarian Educators Association, Volume 12 (2019) DOI: 10.5195/ahea.2019.351

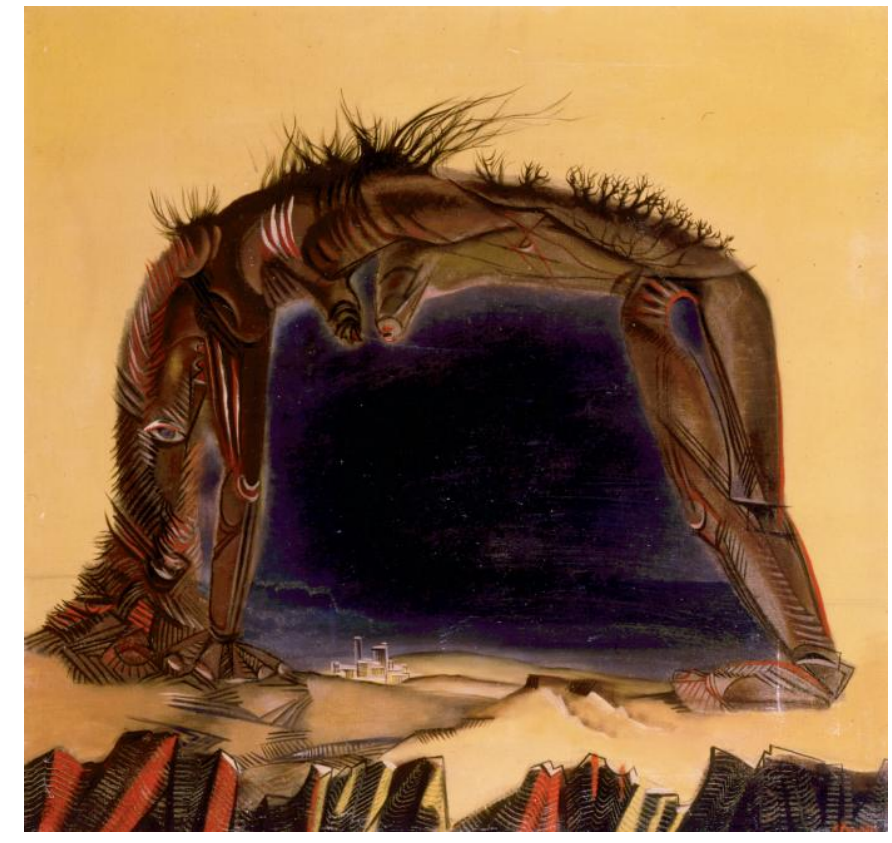

Roland Penrose, Egypt, 1939, oil on canvas [Source: "Surreal Cairo" by Raphael Rubinstein]

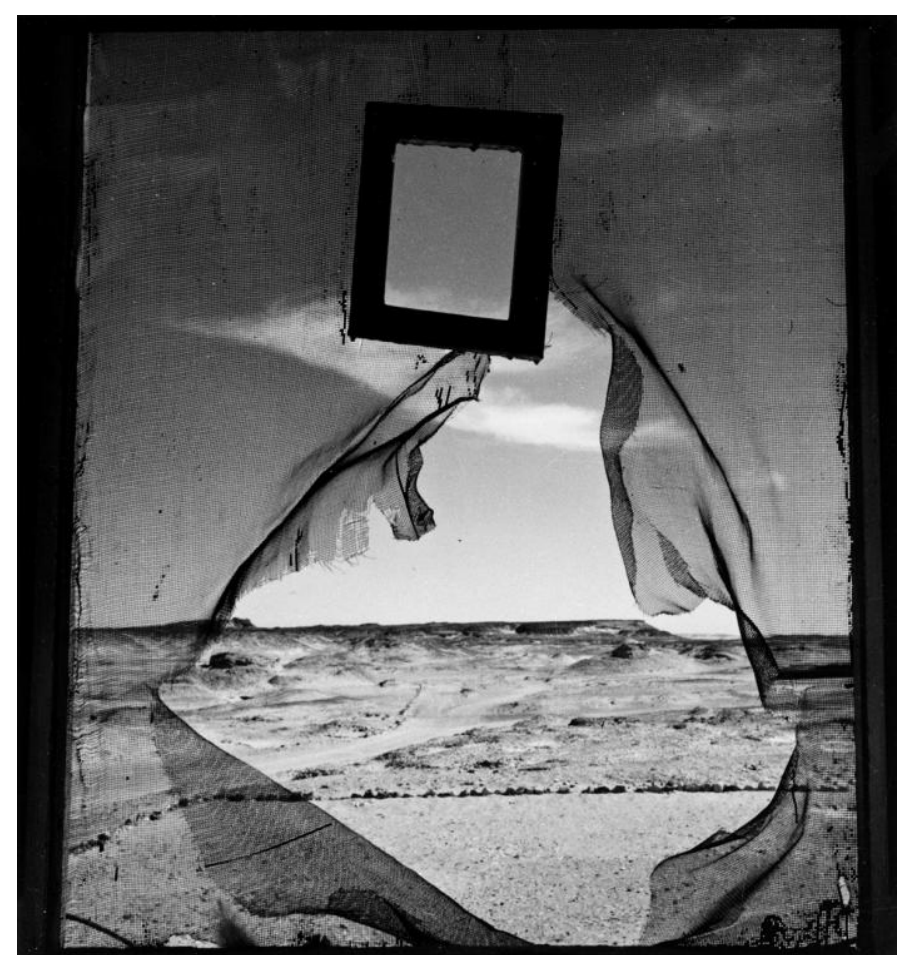

Lee Miller, Portrait of Space, Al Bulwayeb, Near Siwa, Egypt, 1937 [Source: "Surreal Cairo” by Raphael Rubinstein] 


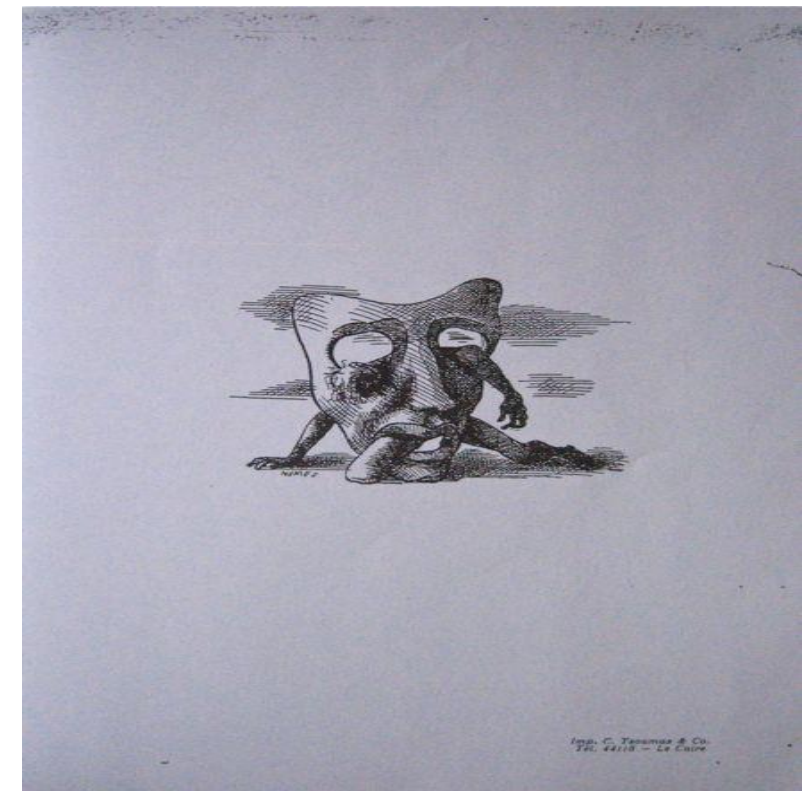

Drawing by Eric de Némes in La séance Continue, back cover [Source: egyptiansurrealism.com]

Evidently, Éric de Némès apparently assumed a French ancestry or lineage by adding the non-Hungarian "de" to his surname. He was even described as or thought to be a "Bulgarian" artist (see Gharieb 1986). However, his impulse to move to and settle in the Middle East or specifically Egypt was far away from being an Orientalist one. To assume that he was a member of the Hungarian Jewry, Éric de Némès's motivation to immigrate had to do with escaping the anti-Jewish measures and even massacres in Central Europe during the interwar period. However, he could not help avoiding the feelings of a "refugee," one that Némès categorically shared with other Jewish Hungarian refugees like Etienne Sved. This "refugee" experience, which was more or less common even among notable European/foreign residents including proto-citizens who had migrated and settled in Ottoman lands/the Middle East. To mention a few famous examples, works by the British novelist Lawrence Durrell (Rodenbeck 2001: 144) and the Greek Tsirkas (Papargyriou 2009: 201) are closely associated with the refugee-feeling of existing as foreigners who "lived as hybrids, themselves on the margins, expat, emigré, enemy alien, and refugee, caught uneasily, more or less comfortably, between colonizer and colonized, expelled from the "West' but never really leaving it behind" ("Atina Grossmann - Trauma" 2017: n.pag.). To use Papargyriou's words, while living in a "double exile", de Némès adapted his national Hungarian lineage to his new residence country due to the World War II conditions that led "the Egyptian government" to suspend "diplomatic relations with all countries at war with Great Britain" (Lugol 1945: 304), including Hungary. He consequently took refuge in his almost immediate affiliation to an Egypt-based, largely French-influenced global art movement.

Belonging to a group that was "neither 'imitators of a European movement' nor 'upholders of an Egyptian identity,", (Makar 2017: n.pag.) de Némès and his non-Egyptian fellow artists functioned in a third-space that spiraled ambivalence and paradox. United under the banner of Vive l'Art Dégénéré! ['Long Live Degenerate Art'], which was the chosen title for the bilingual (French/Arabic) manifesto, both the Egyptian and French Surrealist groups protested 
against Fascism and Nazism atrocities as well as against the ban Hitler effected to modern art under the pretext that such art was degenerate (Beránek 2005). Largely due to differences in cultural and political standpoints, discrepancies nevertheless occurred between the Egyptian and French groups, so it was decided to be "organized under the common label Ma'ärid al-fann alhurr" (208) ['Exhibitions of Free Art,'] in which de Némès was an active participant. He also participated in "the Alexandria Biennale in 1955, and was known for his illustrations of works [by European authors] like Paul Valéry's La Jeune Parque, and Dante's Inferno" (alSibaie 2015: n.pag.). The broad range of de Némès's literary and artistic circle and contact is certainly impressive, particularly when it is evident that it was expanded to include even U.S. expatriates during his (and their) stay in Egypt in the early 1960s. In her memoir The Heart of a Woman (1981), Maya Angelou (2009) recalled that she encountered Éric de Némès "while both were for the Arab Observer, an English language news magazine" (Rubinstein 2017: 85n). She described him as the layout artist, who showed her where an article was placed on a page, its typeface, even the color of ink, were as important as the best-written copy.

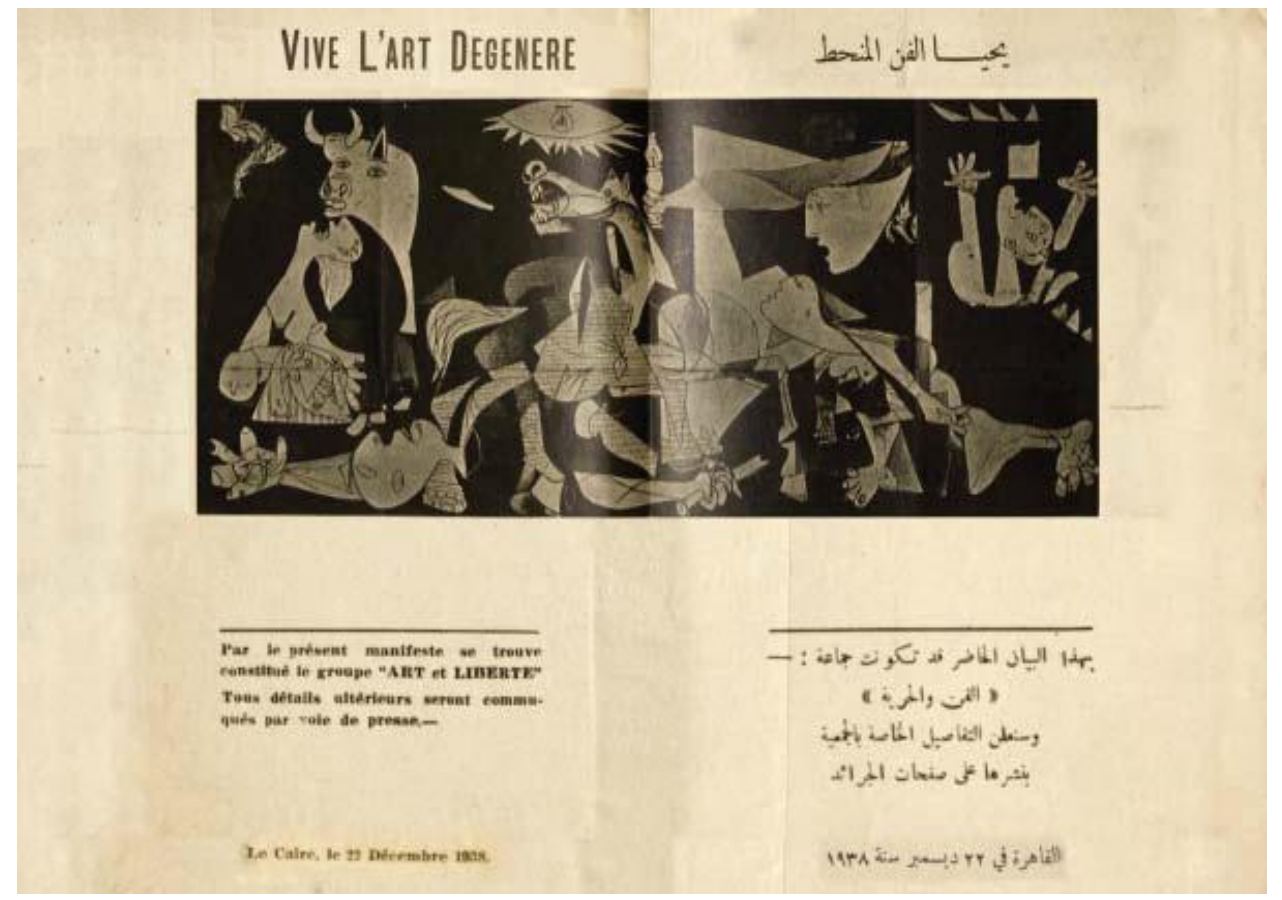

Founding Manifesto of Art et Liberté Group, Vive l'Art Dégénéré, December 22, 1938, Scottish National Gallery of Modern Art Archive, Édimbourg

Némès's work was likewise exemplary when it came to Egyptian-European dialogue and collaboration. Evidently, "there were significant Anglo-Egyptian dialogues," Rubinstein mentions, "among them one of the most extensive examples of literary-artistic collaboration in the show: fourteen delicate ink-and colored-pencil drawings by Eric de Nemes illustrating an unpublished war-themed poem by British poet John Waller" (83). De Némès is also credited for his illustrations of Poetry of Our Times (Thoth Bookshop, Cairo, 1943), which is an anthology of Cairo-based Anglophone poets, some of whom are associated with Personal Landscape poets (Bardaouil 2016). Némès even tried his hand in illustrating children literature books. Early in 
1936, he illustrated Marie Cevers's book, Histoire de Chouchou ['History of Chouchou'], which was published by Desclée de Brouwer in Paris. Moreover, celebrated Egyptian authors and publishers like the Egyptian feminist poet, editor and journalist Durrīyah Shafiq (1908-1975) featured de Némès's work La femme dans l'art copte ['The Woman in Coptic Art'] in her French-language book Art copte (Cairo: La Femme Nouvelle, 1951). In his blog Onpaper, Raphael Cormack (2018) maintained that de Némès's work was also known among Egyptian publishers and that there is evidence that he did illustrations for the al-Ma'arif editions of Ahmed al-Sawi's books.

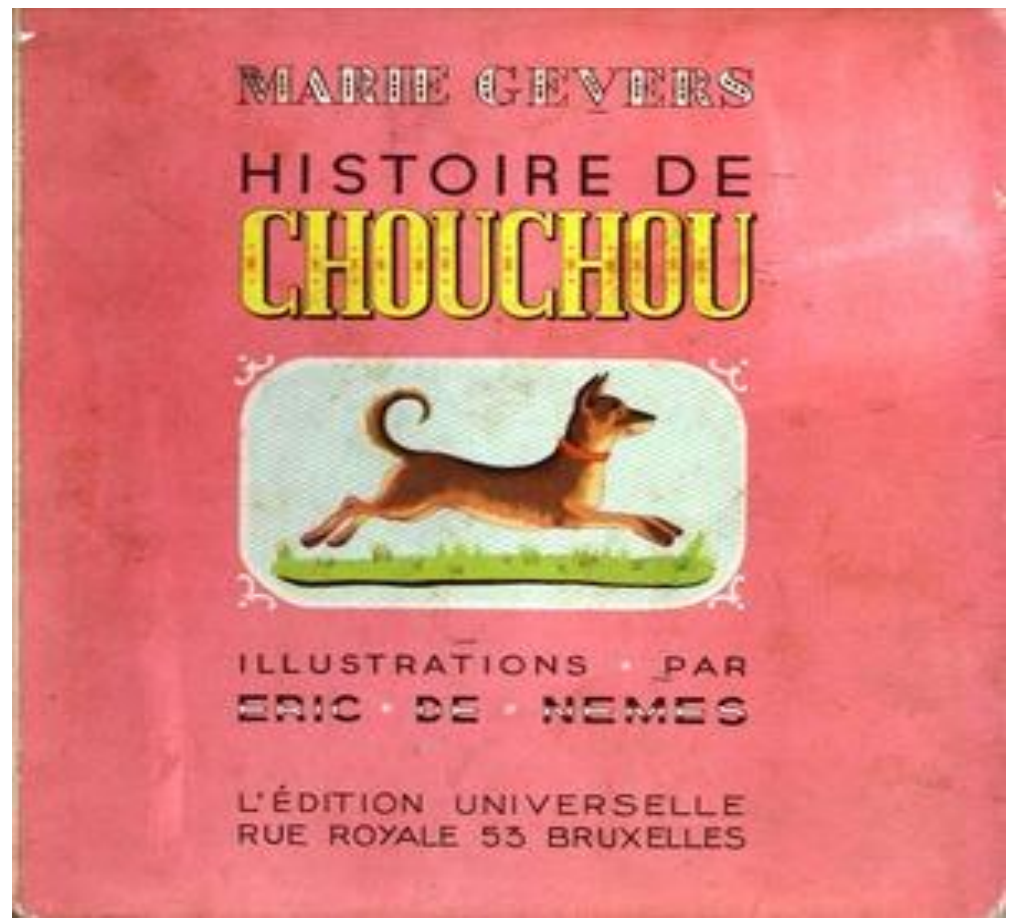

Histoire de Chouchou ['History of Chouchou'], Éric de Némès, 1936 
Mahmoud, Alaaeldin. "Beyond the Colonial/Orientalist Encounter: "European" Cultural Contributions to Arab Modernity." Hungarian Cultural Studies. e-Journal of the American Hungarian Educators Association, Volume 12 (2019) DOI: 10.5195/ahea.2019.351

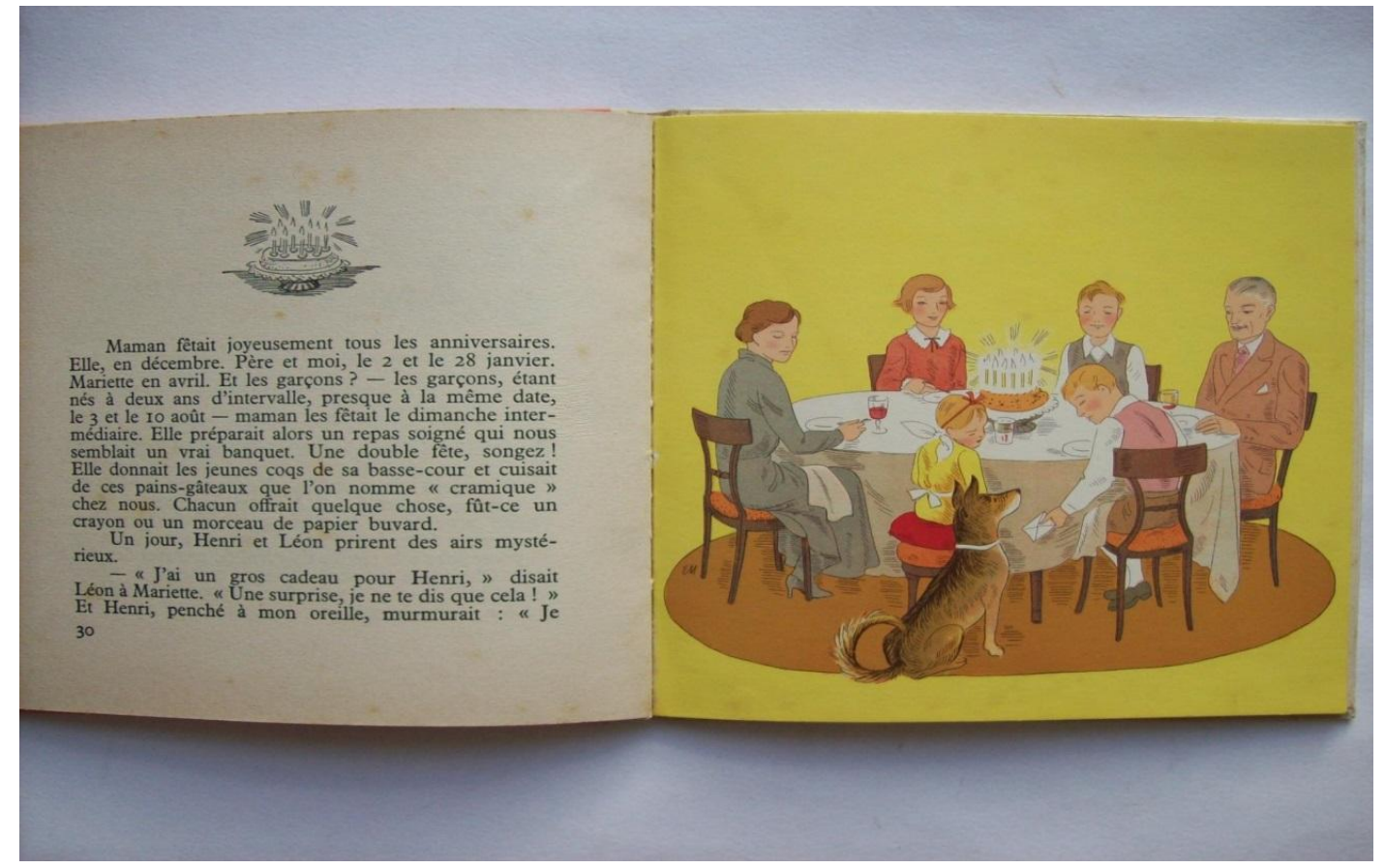

An illustration from Histoire de Chouchou ['History of Chouchou'], Éric de Némès, 1936

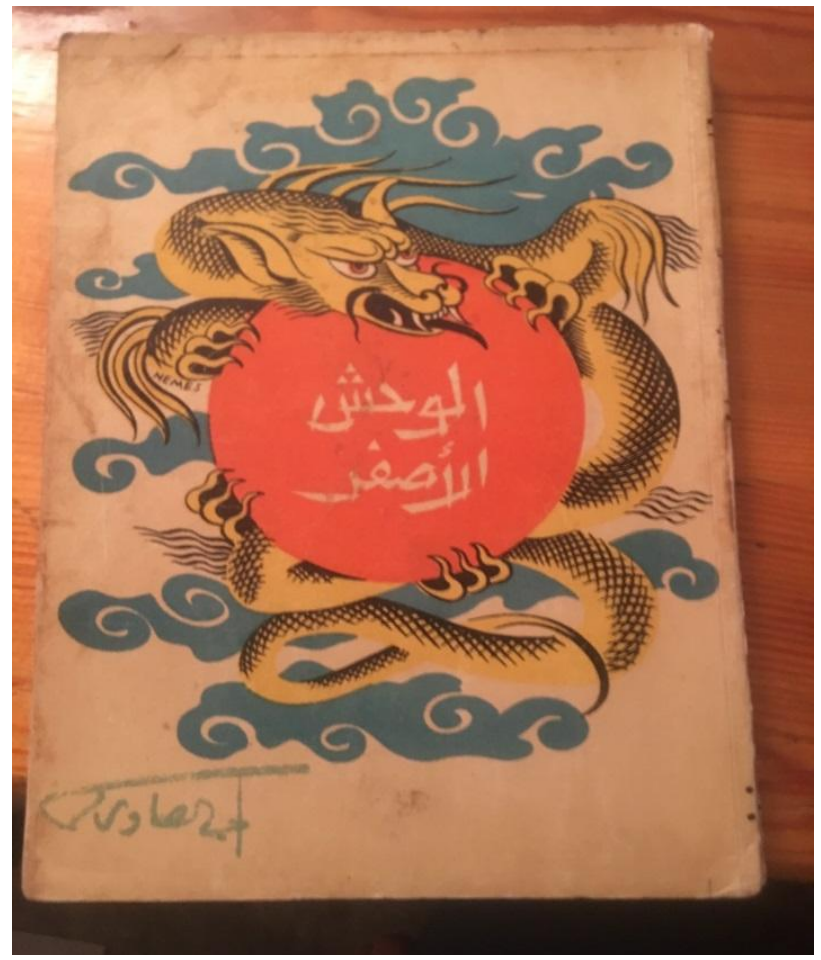

Book cover of Ahmed al-Sawi’s “Al-waḥsh al-așfar” ['The Yellow Monster'], Éric de Némès, [Courtesy of Raphael Cormack] 


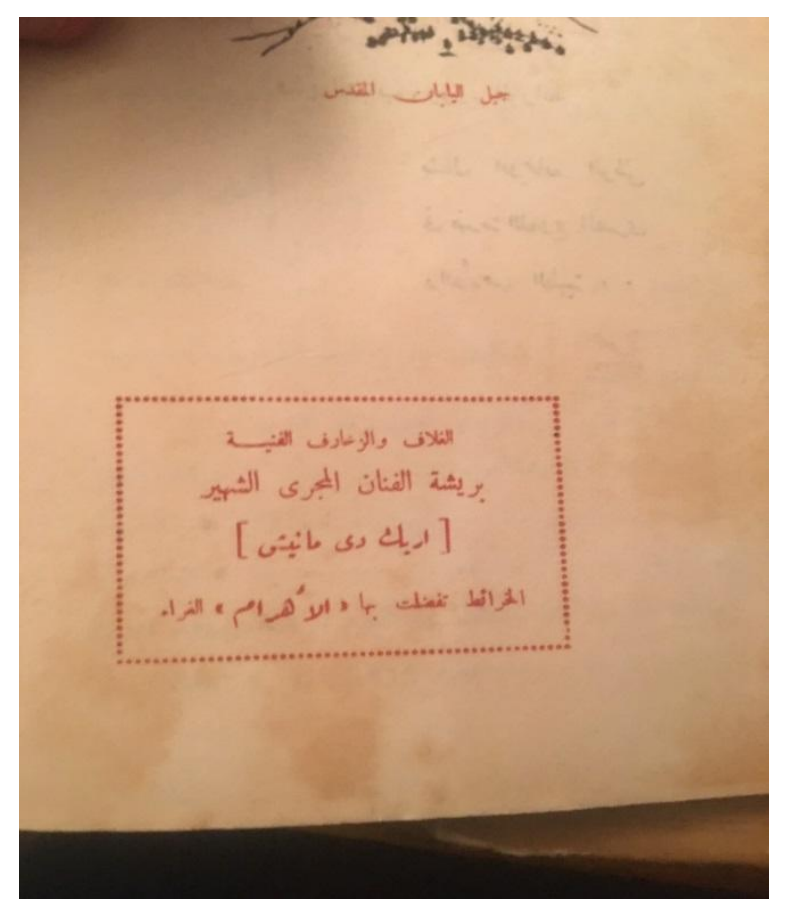

Cover and illustrations of “Jabal al-Yābān al-Muqaddas" ['The Sacred Mountain of Japan'], Éric de Némès, [Courtesy of Raphael Cormack]

Another example of such a collaboration by de Némès was the satirical magazine $a l$ Kashkul ("The Notebook"), founded to be the voice of the anti-colonial al-Wafd Party in 1921, which attested to a successful cooperation between the Spanish-Egyptian cartoonist Juan Santez (variably spelled as Sintes) and the Egyptian zajal ['often oral, strophic Arab verse in a colloquial dialect'] poet and writer Husayn Shafĩq al-Mișrī, who was probably "[t]he caption writer for the cartoons drawn by Santez" (Rifaey and Zuhur 2001: 392). Like de Némès and other European artistic and cultural contributors, Juan Sintes was, as Dougherty (2000) maintains, extremely successful at capturing in his drawings and caricatures, what he called "an essential, authentic "Egyptianness'" (263). 


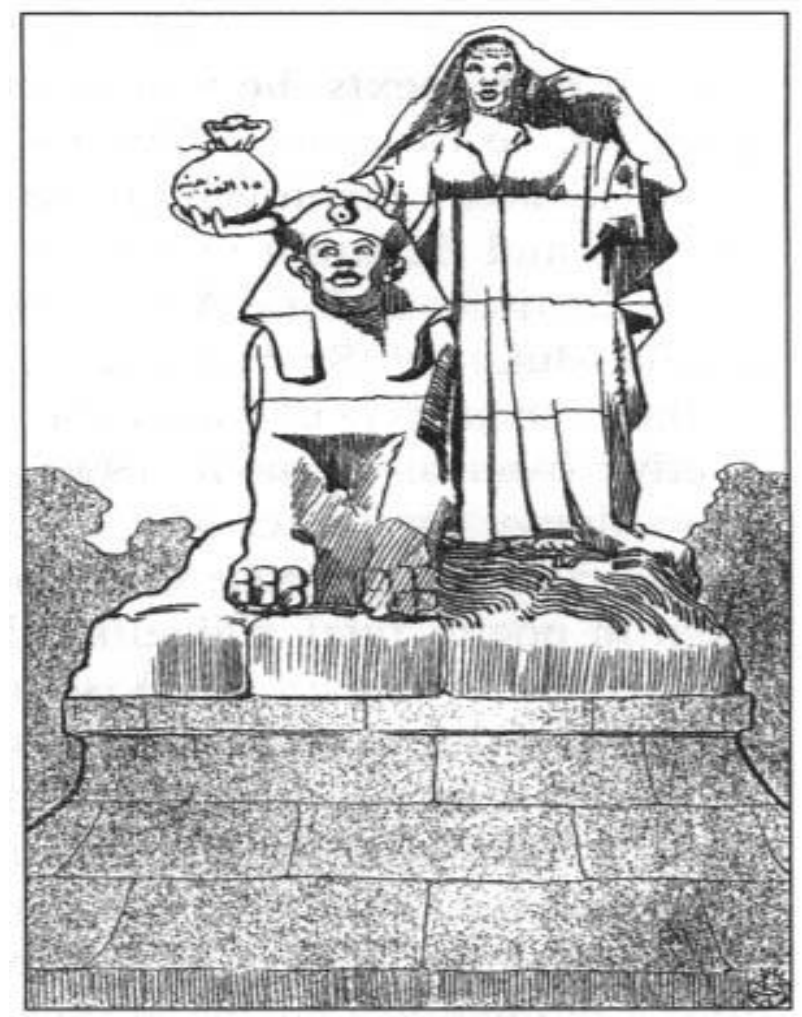

Visible Changes in the Statue 'Nahdat Misr,' Juan Santez, Al-Kashkul. June 18, 1922 [Source: Colors of Enchantment edited by Sherifa Zuhur]

This bi-national duo between Santez and al-Mișrī not only premiered the Egyptian cartoon scene of the time, but was also a precursor to more fruitful encounters along the road, markedly when the Armenian cartoonist Alexander Sarukhan (1898-1977) was contracted by the actress Fāṭma al-Yūsuf (1898-1958) for her newly founded newspaper Ruz al-Yusuf in the mid1920s. What both Santez/Sintes and Sarukhan shared was their exceptionally profound understanding of the Egyptian ambience of the time as well as their genuine integration with the agents of the vibrant cultural life in Egypt during the twenties, thirties and the forties of the twentieth century. Juan Sintes, for example, was not only active amongst the "foreign" art critics of various European nationalities "residing in Egypt [who] took an interest in writing about the Egyptian art scene during the first half of the twentieth century" (Saadedin 2016: n.pag.) like Jean Moscatelli, Etienne Mériel, Robert Blum, Charles Boeglin, Morik Brin, Comte Philippe d'Arschot, and Dimitri Diacomidis (Saadedin 2016), but also within Egyptian artistic circles, where Juan Sintes was grouped together with "al-Misri...Umm Kulthum, 'Abd al-Wahhab, al'Aqqad, Fikri Abaza, Husayn Haykal, and a constellation of similar 'stars' of culture... at least on the [al-Kashkul] magazine's pages, to form an imaginary 1934 Egyptian version of the Algonquin Round Table" (Dougherty 2000: 263). 


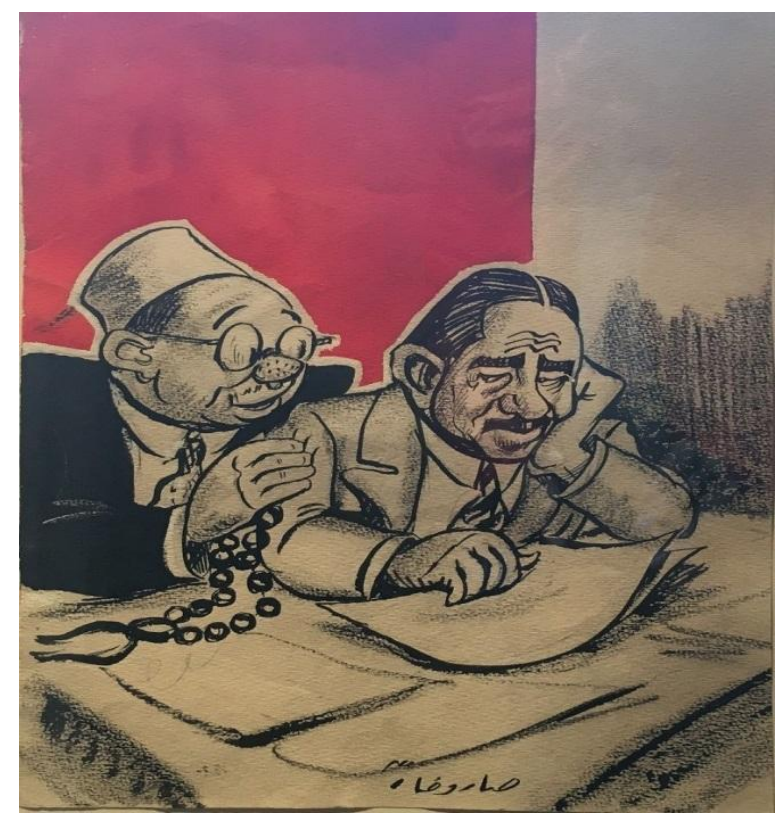

Egyptian Effendi and the Egyptian Prime Minister Ali Maher Pasha, Alexander Saroukhan [Source: Artcentron]

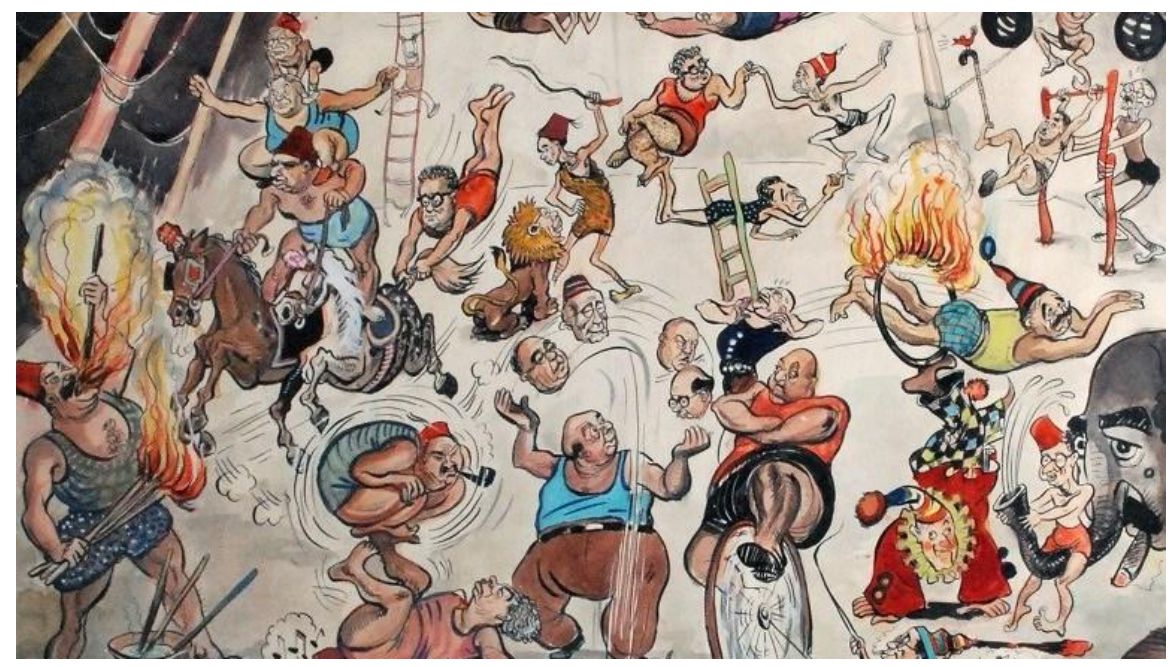

A Political Circus, Alexander Saroukhan, Al Masar Gallery [Source: Artcentron]

The overriding impact of Sintes, Sarukhan, and Rifqi of Turkey went beyond the fact that they were "the foreign fathers of modern Egyptian caricature," (Ettmüller 2012: 141) but also that "They taught the first generation of Egyptian caricaturists, Rakha (1911-1989), 'Abd asSami‘(1916-1985), Salah Jahin (1930-1986) and George Bahgouri (b. 1932), whose cartoons were eagerly followed in different newspapers and satirical magazines" (141-42). 
Mahmoud, Alaaeldin. "Beyond the Colonial/Orientalist Encounter: "European" Cultural Contributions to Arab Modernity." Hungarian Cultural Studies. e-Journal of the American Hungarian Educators

Association, Volume 12 (2019) DOI: 10.5195/ahea.2019.351

\section{Conclusion}

Especially in connection to those Europeans who immigrated and settled in Egypt and the Levant starting from the second half of the nineteenth century and culminating in the interwar period, the various contributions made in pedagogy, theater, photography, journalism, caricature, painting and book illustration by foreign teachers and artists to the "indigenous" Ottoman/Arab modernity have often been overlooked or overshadowed by highlighting the indebtedness "world" modernities have to the so-called "European" modernity following the colonial and/or orientalist encounter. Indeed, European colonizers and orientalists have their own, solid contributions to the burgeoning modernities around the world, including the Ottoman/Arab one. However, it is evident that the Europeans who originated from countries with no recent colonial history with Egypt and the Levant, such as Greece or countries with no colonial history with the region like Hungary, Austria, Italy and Malta, can also lay claim to their equally solid cultural contributions to the Arab modernity in their respective fields of expertise.

The cosmopolitan urban centers such as Alexandria, Cairo, and Beirut, which emerged in Egypt and Syro-Lebanon, were in fact contact zones where grappling or contesting occurred at times, yet collaborative, European and indigenous modernities also co-existed and thrived at these same sites. On the state level, the Ottoman governors of the Arab provinces commissioned European teachers to "modernize" a once-traditional education, while on the non-state level, an increasing number of charity societies were launched by representatives of both European and local communities for numerous purposes, pedagogical ones included. Moreover, the unfavorable political and economic conditions in Europe (especially in Central Europe) which intensified during the interwar period coupled with the emergence of a more welcoming ambience for foreigners in Egypt's and the Levant's (cosmopolitan) urban centers, led to the immigration of a second wave of European professionals to Egypt and the Levant like Zoltan Kluger, Etienne Sved, and Éric de Némès, who genuinely and collaboratively integrated into the existing vibrant cultural and artistic scenes of the time. The work of Alexander Sarukhan, Juan Santez/Sintes, along with de Némès does not only showcase that they somehow assimilated the Egyptian geist of the time, capped by Sarukhan's famed cartoon character "El Masri Efendi" ("The Egyptian Efendi,") but also that artists like Sarukhan and Santez/Sintes were the real nonEgyptian fathers of modern Egyptian caricature.

\section{Works Cited}

Al-Imam, Muhammad Rif'at. 1999. Tārīkh al-jāliyah al-Armanīyah fì Miṣr: al-qarn al-tāsi ‘ 'ashar ['The History of the Armenian Community in Egypt: The Nineteenth Century']. Cairo: al-Hay'ah al-Misriyah al-'Ammah lil-Kitab.

Al-Sibaie, Bashir. 2015. "Mukhtārāt min a'māl kātib suryālī." ['Selections from the Works of a Surrealist Writer']. Al-Hewar Al-Mutamaddin 4810. May 18. http://www.ahewar.org/debat/show.art.asp?aid=468491\&nm=1

Angelou, Maya. 2009. The Heart of a Woman. New York: Random House Trade Paperbacks.

"Art et Liberté: Rupture, War and Surrealism in Egypt (1938 - 1948)." 2019. Art Reoriented. April 28. http://www.artreoriented.com/exhibitions/art-et-liberte 
Mahmoud, Alaaeldin. "Beyond the Colonial/Orientalist Encounter: "European" Cultural Contributions to Arab Modernity." Hungarian Cultural Studies. e-Journal of the American Hungarian Educators Association, Volume 12 (2019) DOI: 10.5195/ahea.2019.351

"Atina Grossmann - Trauma, Privilege and Adventure in Transit: German Jewish Refugees in Iran and India." 2017. Alan D. Leve Center for Jewish Studies. May 1. https://www.cjs.ucla.edu/atina-grossmann-trauma-privilege-and-adventure-in-transitgerman-jewish-refugees-in-iran-and-india/

Bardaouil, Sam. 2016. Surrealism in Egypt: Modernism and the Art and Liberty Group. London: I.B.Tauris. June 25. https://books.google.com.kw/books?id=eVXGDQAAQBAJ\&printsec=frontcover\&dq=ed itions:lctL-

N8kq0AC\&hl=en\&sa=X\&ved=0ahUKEwieh8nJqYTjAhX1nFwKHW80AngQ6AEIJzA $\mathrm{A} \# \mathrm{v}=$ onepage $\& \mathrm{q} \& \mathrm{f}=$ false

Beránek, Ondřej. 2005. "The Surrealist Movement in Egypt in the 1930s and the 1940s." Archiv Orientální 73.2: 203-222.

Cole, Juan Ricardo. 1999. Colonialism and Revolution in the Middle East: Social and Cultural Origins of Egypt's 'Urabi Movement. Cairo, Egypt: The American University in Cairo Press.

Cormak, Raphael. 2018. "Eric de Nemès: a Hungarian Illustrator in Cairo.” February17. https://onpaper.blog/2018/02/17/eric-de-nemes-a-hungarian-illustrator-in-cairo/

Cutler, Brock. 2014. Review of Medicine and the Saints: Science, Islam, and the Colonial Encounter in Morocco, 1877-1956, by Ellen J. Amster. Isis 105.4: 851-852.

Dougherty, Roberta L. 2000. "Badi'a Masabni, Artiste and Modernist: The Egyptian Print Media's Carnival of National Identity.” In Mass Mediations: New Approaches to Popular Culture in the Middle East and Beyond. Ed. Walter Armbrust. Berkeley: University of California Press.

Eaman, Ross. 2009. Historical Dictionary of Journalism. Lanham, MD: Scarecrow Press.

Ettmüller, Eliane Ursula. 2012. "Caricature and Egypt's Revolution of 25 January 2011." Zeithistorische Forschungen/Studies in Contemporary History 9: 138-148. http://www.zeithistorische-forschungen.de/1-2012/id=4469

Gharieb, Samir. 1986. Surrealism in Egypt and Plastic Arts. Cairo: Ahram Commercial Press. Hanioğlu, M. Şükrü. 2012. "The Historical Roots of Kemalism.” In Democracy, Islam, and Secularism in Turkey. Eds. Ahmet T. Kuru, Alfred Stepan. New York: Columbia University Press.

Khuri-Makdisi, Ilham. 2010. The Eastern Mediterranean and the Making of Global Radicalism, 1860-1914. Berkeley and Los Angeles, California: University of California Press.

Krishna, Sankaran. 2009. Globalization and Postcolonialism: Hegemony and Resistance in the Twenty-First Century. Lanham, Maryland: Rowman \& Littlefield.

Liverpool, Tate. 2017. "John Piper; Surrealism in Egypt: Art et Liberté 1938-48 - review." November 19. https://www.theguardian.com/artanddesign/2017/nov/19/john-pipersurrealism-in-egypt-tate-liverpool-review

Lugol, Jean. 1945. Egypt and World War II: The Anti-Axis Campaigns in the Middle East. Trans. by A. G. Mitchell. Cairo: Société Orientale de Publicité.

Makar, Johannes. 2017. Review of Surrealism in Egypt: Modernism and the Art and Liberty Group, by Sam Bardaouil. LSE Reviews of Books. May 12. https://blogs.lse.ac.uk/lsereviewofbooks/2017/05/12/book-review-surrealism-in-egyptmodernism-and-the-art-and-liberty-group-by-sam-bardaouil/ 
Mészáros, Ágnes. 2016. “Otto Schoefft in Egypt: A Photographer from Hungarian Painters Dynasty." In Visualizing the Orient: Central Europe and the Near East in the 19th and 20th Centuries. Eds. Adéla Jůnová Macková, Lucie Storchová, and Libor Jůn. Prague: Academy of Performing Arts in Prague (AMU)/Film and TV School of Academy of Performing Arts in Prague (FAMU).

Nassar, Issam. 2000. "A Jerusalem Photographer: The Life and Work of Hanna Safieh.” Jerusalem Quarterly 7: 24-28.

Papargyriou, Eleni. 2009. "The Poetics of Transit: Exile, Diaspora, and Repatriation in Stratis Tsirkas's Novels." Greek Diaspora and Migration since 1700: Society, Politics and Culture. Ed. Dimitris Tziovas. Burlington, VT: Ashgate.

Pratt, Mary Louise. 1991. "Arts of the Contact Zone.” Profession, 33-40.

Rifaey, Tonia and Sherifa Zuhur. 2001. "Visualizing Identity: Gender and Nation in Egyptian Cartoons." In Colors of Enchantment: Theater, Dance, Music, and the Visual Arts of the Middle East. Ed. Sherifa Zuhur. Cairo and New York: The American University in Cairo Press.

Ritter, Markus, and Staci G. Scheiwiller. Eds. 2018. The Indigenous Lens? Early Photography in the Near and Middle East. Berlin: De Gruyter.

Rodenbeck, John. 2001. "Alexandria in Cavafy, Durrell, and Tsirkas." Alif: Journal of Comparative Poetics 21: 141-160.

Rubinstein, Raphael. 2017. "Surreal Cairo.” Art in America 105.2: 76-85.

Saadedin, Magda. 2016. "Articulating Art: Writing about Modern Art in Egypt." RAWI 8. https://rawi-magazine.com/articles/articulating_art/

Sadgrove, Philip. 1996. The Egyptian Theatre in the Nineteenth Century: 1799-1882. Reading: Ithaca Press.

Said, Edward W. 1994. Orientalism. 25th Anniversary Edition With a New Preface by the Author. New York: Random House, Inc.

Sela, Rona. "In the Eyes of the Beholder - Aspects of Early Palestinian Photography." June 17. https://www.academia.edu/36679969/In_the_Eyes_of_the_Beholder_Aspects_of_Early_Palestinian_Photography

Türköz, Meltem. 2018. Naming and Nation-building in Turkey: The 1934 Surname Law. New York, NY: Palgrave Macmillan.

Woodward, Michelle. 2003. "Between Orientalist Clichés and Images of Modernization: Photographic Practice in the Late Ottoman Era." History of Photography 27.4: 363-374.

Zaydan, Jurji. 2013. Tārīkh ādāb al-lughah al- 'Arabìyah. ['The History of Literatures in the Arabic Language']. Cairo: Hindawi Foundation for Education and Culture. 